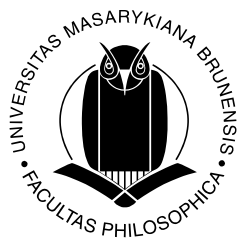

\title{
Supernatural Substitution and Abduction IN THE DRAMA OF THE IRISH REVIVAL
}

\begin{abstract}
This article investigates the ways in which the playwrights of the Irish Revival recycled local folk legends of fairy abductions which often featured stocks pieces of magical wood moulded to resemble a human being - and changelings, supernatural beings secretly left in place of the kidnapped people and one of the most uncanny, familiar, yet disturbingly strange, liminal creatures in Irish folklore. After a brief overview of the cultural and aesthetic values of the period under discussion, and the most significant aspects of Irish folk stories of supernatural abductions and substitutions, I will examine plays written by William Butler Yeats and George Fitzmaurice that explicitly allude to these beliefs. In particular, I will focus on the question of whether these playwrights preserved the ambiguous and often menacing nature of the supernatural substitution in their works and whether they embraced those aspects of the traditional stories that could potentially have challenged the popular, idealized, pastoral image of Ireland.
\end{abstract}

\section{Keywords}

Irish Revival; Irish drama; fairies; changelings; fairy abduction; William Butler Yeats; George Fitzmaurice

The popular, idyllic image of Ireland as a rustic, pristine "land of heart's desire," to use Yeats's phrase, emerged at the turn of the nineteenth century which was a crucial period in Irish history during which local traditions were reinvigorated and reinvented. Even though the Irish Revival significantly reinforced the Irish sense of national identity, its mainstream culture is nowadays often re-examined from the contemporary perspective and criticized for being very selective in creating a new concept of Irishness. Such discriminatory strategies were visible, for 
instance, in the fact that certain local traditions, such as the sean nós dance or folk theatre, were neglected because they did not match the new, idealized image of the nation and its culture. In general, as Declan Kiberd notes, the pastoral vision of Ireland was created by means of the re-evaluation of features formerly attributed to Irish people. In his well-known book Inventing Ireland, he explains that "[t] he strategy of the revivalists [...] became clear: for bad words substitute good, for superstitious use religious, for backward say traditional, for irrational suggest emotional" (Kiberd 1996: 32). The change did not so much relate to the country itself, but rather to its perceptions and cultural representations. One of the most famous examples of the new, Arcadian image of the island can be found in the much-quoted excerpt from Eamon de Valera's address delivered on Saint Patrick's Day in 1943, in which he presented a vision of the Irish countryside that "would be bright with cosy homesteads, whose fields and villages would be joyous with sounds of industry, the romping of sturdy children, the contests of athletic youths and the laughter of comely maidens, whose firesides would be the forums of the wisdom of serene old age" (1991: 748). He envisaged Ireland as a prosperous country whose inhabitants are wise, industrious, strong, healthy, and conventionally beautiful.

It is possible to mention a number of practical means and incentives intended to bring this ideal to life. In his analysis of the manner in which Irish Homestead - a weekly published by the Irish Agricultural Organisation Society between 1895 and 1918 - shaped traditional female gender roles in Ireland, D. A. J. MacPherson discusses the efforts that its editors made to broaden the appeal of the Irish countryside. Importantly, some of their endeavours were specifically aimed at improving the aesthetic aspects of rural Ireland. MacPherson, for instance, mentions the 1901 competition to promote various indigenous pastimes as well as to "[c]rusade against badly kept and dirty homesteads," which involved "the beautifying of cottages by cultivation of flowers, shrubs and vegetables, removal of dung heaps, etc." (2012: 41). Such aesthetically pleasant places were designed for good-looking and morally upright people - both men and women alike - who had shed the burden of their country's traumatic past. While the angelic model of Irish femininity, for instance, found reflection in Irish dance in the figure of decently dressed women performing airy slip jigs, the new image of Irish masculinity was effectively promoted by the Gaelic Athletic Association. As Patrick F. McDevitt notes, "[t]he athlete's beautiful, healthy, and vigorous Irish male body countered the Victorian English characterizations of the Irish as either simian, drunken ruffians, or effeminate and feckless, childlike inferiors in need of Anglo-Saxon domination" (2004: 18). Last but not least, the Abbey, Ireland's first national theatre, played a special role in shaping and promoting the aestheticized image of rural Ireland as "the home of an ancient idealism" (qtd. in Gregory 1991: 9). Its stage was for many years dominated by idyllic representations of the Irish countryside in so-called peasant plays which largely focused on the virtuous lives of noble Irish peasants.

One of the major fields of interest of the representatives of the Irish Revival, including many playwrights associated with the Abbey such as W. B. Yeats and 
Lady Gregory, was Irish folklore including local fairy lore. As Diane Purkiss argues, this can be seen as an expression of a nostalgic longing for an idealized, pre-colonial Irish past. Addressing the depiction of fairies in Yeats's The Land of Heart's Desire, she maintains that "[t] hey represent an Irish culture that has been kept pure and intact from before the conquest" (Purkiss 2007: 324). Consequently, it is logical to suspect that this desire to bring back to life an idealized image of the past may have necessitated a selective attitude towards Irish folk legends and traditions. In order to verify this thesis, it is useful to examine certain disturbing aspects of the Irish stories of fairy substitution, which do not fit with the romanticized vision of rural Ireland.

According to Irish folklore, two groups of people were in particular danger of being abducted and replaced by changelings: children, and women who were in transitional states (i.e. new mothers and wives). Most contemporary scholars agree that it is possible to provide a rational explanation for this belief. Speculating about the origins of fairy lore, Purkiss explains that "[i]t appears that the human mind cannot bear very much blankness - where we do not know, we invent, and what we invent reflects our fear of what we do not know" (2007: 19). As regards children, Susan Schoon Eberly provides convincing evidence that many of the descriptions of changelings correspond to specific congenital disorders, which "evoked a [...] response of mingled awe and fear" (1988: 59). As Julia Kristeva explains, otherness defined through disability is associated with the deepest, catastrophic fears rooted in the human psyche, which lead to rejection, indifference, and arrogance. This is so because in facing disability we are also confronted with the limits of existence, the fear of ultimate loss, and the threat of death (Kristeva 2012: 38-9). Thus, the very concept of a changeling and its supernatural provenance can be seen as an attempt to come to terms with the birth of a disabled child, in a time when medicine could not provide sufficient rational explanation for such phenomena. This corresponds to what is commonly referred to as the religious or moral model of disability, which is also often described as the symbolic model, as it envisages disability as a symbol of divine election or punishment - an attitude commonly seen as prevalent in pre-industrial rural societies.

The other group perceived as particularly prone to abduction by fairies were women. They would frequently have been considered changelings if they had not been successful in the roles of wives and mothers that Irish society had prescribed for them. As the storyteller Jenny McGlynn explains,

... people change; they have to get used to a new way of life when they get married. And some can take it and some can't. Some women can be good wives and mothers. Others can't take it [...]. So I think it is just like today's broken marriages; you hear more about them today than you did then. They would say that she [the wife] was a demon, that she wasn't from this earth at all, that she was one of the changelings. I think that's what it was all about. (qtd. in Lysaght 1997: 36) 
These beliefs, which often served as justification for the violence directed at those labelled as the Other, were still alive in the times of the Irish Revival. One of the most appalling examples was that of Bridget Cleary, a woman from co. Tipperary. In 1895 , Cleary was immolated by her husband, who later explained that he had suspected she was a changeling.

As Séamas Mac Philib notes, "[t]he most common method of ridding oneself of the changeling both in Ireland and elsewhere is to burn it. Other methods of banishment include beating, exposure, use of charms, herbs and casting into rivers" (1991: 129). This is likely because it was believed that when fairies saw one of their own being maltreated, they would return the abducted human to his or her rightful place. As we learn from an 1887 article by the famous American ethnographer of Irish descent James Mooney,

In such cases, when there is no longer any doubt in the matter - for mothers are always slow to be convinced of the real truth - the fairy woman is called in to bring back the stolen child. Her usual method is to heat the shovel in the fire, place the changeling upon it and put it out upon the dunghill. She then returns to the house and recites certain words, after which the family go out to the dunghill and find there the real child, in place of the other, which has been taken away again by the fairies (1887: 140).

This is followed by the sad conclusion that " $[\mathrm{t}]$ he child seldom lives long after its return, owing to the rough treatment it receives while in the hands of the fairies" (Mooney 1887, 140-1). This sheds some light on the tragic fate of many of the children who were subjected to similar treatment by their parents. Importantly, as Mac Philib argues, "it seems that any unusual or non-conformist behaviour in a child could lead to it being labelled a changeling" (1991: 131). He gives the example of a young man who stayed in bed all day, did not go to mass, but had an excellent memory (1991: 131). ${ }^{1}$ This report broadens the category of "changeling" and also highlights the violent ways in which undesirable misfits were frequently treated by rural Irish communities. Consequently, we can assume that more often than not Irish folk stories about changelings were considered as spoiling the afore-mentioned romanticized image of pastoral Ireland, presenting the Emerald Isle as a deeply prejudiced place in which individualists, visibly disabled persons, or those who for any other reason did not conform to the physical or behavioural "norm" rarely met with acceptance and understanding.

With all this in mind, it seems worthwhile to devote some time to exploring the changeling motif in the works of the two playwrights, Yeats and Fitzmaurice, who in one way or another were associated with the Abbey Theatre. Although their dramatic styles greatly differed, both of the dramatists in question challenged the popular convention of Irish peasant plays in their own unique ways, infusing some of their works with rich allusions to Irish changeling lore. My analysis of these allusions will help answer the following questions: what is the role of changeling lore in the works of these two playwrights? Do they in any 
way address the perception of disability as a form of otherness that evokes strong reactions of fear and denial and rarely leads to acceptance? Do the stocks and changelings depicted in the plays under discussion fit in with the standards of beauty and propriety promoted by the Irish revivalists?

Direct allusions to changeling lore and fairy abductions can be found in both Yeats's poetry (e.g. in "The Stolen Child," "A Faery Song," and "The Host of the Air") and in two of his plays: "The Land of Heart's Desire" (1894) and "The Only Jealousy of Emer" (1919). The former tells the story of a young wife, Mary Bruin, who is deeply dissatisfied with the limitations of her new social role and the materialistic attitude of her parents-in-law. On May Eve, the house in which she lives with her husband and in-laws is visited by a child who turns out to be a fairy. The fairy enchants Mary with a dance and lures her away to the Land of the Young (Tír na nÓg / Tirnanogue), "Where beauty has no ebb, decay no flood, / But joy is wisdom, time an endless song" (2001c: 78). After Mary dies, her mother-in-law, Bridget addresses her son in the following way: "Come from that image; body and soul are gone. / You have thrown your arms about a drift of leaves, / Or bole of an ash tree changed into her image" (2001c: 72). This is a clear reference to the belief that fairy abductions involve replacing human beings either with old and decrepit fairies or with so-called stocks. As Eberly explains, these were "inanimate, wooden, doll-like beings which soon lost all semblance of life" (1988: 60). In Fairy Folk Tales of Ireland, which he collected and published himself, Yeats describes a stock as "a log of wood so bewitched that it seems to be a mortal pining away, or dying, or being buried" (1998: 48). Emma Wilby further explains that fairy stocks are examples of "false bodies," which according to many tribal beliefs, were "left behind when an individual journeys in subtle form into the spirit realm" (2010: 292), and were "sometimes seen as a false or partial form, as opposed to merely a physical body without an animating soul" (2010: 293). In the play, Bridget then believes that Mary's body and soul have been replaced with a magical object whose role is to deceive onlookers into believing that they are witnessing Mary's death.

What seems additionally striking about the above-mentioned scene is the fact that the stock plays a marginal role in it. This, in a sense, indicates Yeats's ambivalent attitude to the fairyland and the magic of its inhabitants, which according to Peter Alderson Smith, "vacillat[ed] between attraction and repulsion" (1987: 156). Dismissed as a false body, Mary's corpse is seen as lifeless, soulless nonhuman matter, somewhat reminiscent of Martin Luther's infamous comment about "a strange 12-year-old boy at Dessau," who was suspected of being a changeling as he "was said to do nothing but eat voraciously and to excrete" (Miles 2001: 30). Luther reportedly called him "a mass of flesh without a soul" and advised that he be drowned (Miles 2001: 30). A similar, though perhaps less religiously motivated logic of disposability informs Yeats's play. Yeats, who was a keen supporter of eugenics, in his poem "Under Ben Bulben" openly scorned 
$[\ldots]$ the sort now growing up

All out of shape from toe to top,

Their unremembering hearts and heads

Base-born products of base beds. (2000: 303)

Thus, it is no wonder that the stock presented in The Land of Heart's Desire seems neglected both by the characters and by the playwright himself, as he does not provide any specific stage directions that would suggest anything about its appearance, movements, or position. Approached from the Kristevan perspective, the effect this achieves can be seen as a means of diminishing the terror of death. The abject, dying body is seen as an unreal, fake substitute, and thus the comment that Bridget makes relieves the people gathered in the cottage from the moral duty of keeping vigil next to a dying family member. The attention of the characters and the audience is instantly shifted away from what is believed to be a magical piece of wood, towards dancing figures visible outside the cottage and a white bird that presumably represents Mary's liberation from domestic confines. Thus, the beauty, lightness, and airiness of the fairies dancing in their otherworldly realm overshadows the tragedy taking place in the human world, and the menacing presence of Mary's dead body perceived by other characters as an uncanny simulacrum, from which they avert their eyes. In other words, both the audience and the characters are in a way seduced by the young, healthy, and beautiful inhabitants of Tirnanogue whose image, although perhaps more airy and elusive, is not much different from the vision of Irish people presented in de Valera's speech.

Another play by Yeats which features a changeling is The Only Jealousy of Emer. The dramatic text focuses on the eponymous wife of the famous Irish mythological hero Cuchulain and her struggle to bring her husband back from a supernatural underwater world, after he is replaced by a changeling identified as Bricriu, an evil spirit and troublemaker. One of the characteristic features of the changeling is its arm which "is withered to the very socket" (2001d: 322). In his analysis of the play from the perspective of disability studies, Ken Monteith argues that "Cuchulain's body becomes like a prosthetic device for Bricriu, allowing the Sidhe ${ }^{2}$ access to the material world" (2010: 103) and, at the same time, states that "the disabling and possession of Cuchulain's body feminizes and weakens the figure of Cuchulain; however, this also increases that same body's value" (2010: 103). Undoubtedly, the fact that the struggle between Emer and Bricriu takes place over what seems to be Cuchulain's body might suggest that it is an object that both parties wish to possess. However, on closer examination, this interpretation is only partly accurate.

The first question that needs to be asked is: whose body has been washed ashore and is now lying on the bed in grave-clothes? Emer explains:

It may be

An image has been put in his place, 
A sea-born log bewitched into his likeness, Or some stark horseman grown too old to ride Among the troops of Manannan, Son of the Sea. (2001d: 320)

These words suggest that Yeats's vision presented in the play is very similar to the one shown in "The Land of Heart's Desire," in the way it depicts Cuchulain's flesh as a fake body. In the opening song performed by the First Musician, it is described as "A strange unserviceable thing, / A fragile, exquisite, pale shell" (2001d: 318) - an empty container which only bears a resemblance to Cuchulain's real body and is later possessed by Bricriu. Alternatively, it is also possible to argue that the changeling is Bricriu himself - a supernatural creature who used some magical charm to take on Cuchulain's appearance.

Using a medical term, we could describe Cuchulain's condition as comatose, temporarily suspended in a liminal state between life and death, between the human world and the world of Sidhe. Yeats underscores the strong connection between disability and liminal experience, especially death. The withered arm is more than what Monteith calls "a very present reminder of Cuchulain's missing spirit" (2010: 102), which is being seduced by the Woman of the Sidhe while his body remains in the mortal world. ${ }^{3}$ The impairment evokes the fear of ultimate loss. It communicates weakness and fragility, which can be associated with old age. Therefore, it might remind Emer of her greatest desire - to be reunited with her husband and to grow old together. It is, however, conspicuous that she avoids any form of physical contact with Cuchulain's impaired, fake body. As we learn from Cuchulain's mistress, Emer has "not kissed his lips / Nor laid his head upon [her] breast" (2010d: 320). The impaired body turns into an object of repulsion. It is no longer seen as a real body, but a fake object which aims to deceive onlookers. The impaired, liminal, hybrid body which bears the stigma of death is treated by her as a taboo object which evokes feelings of fear, rejection, and even repulsion. This shows that in "The Only Jealousy of Emer" Yeats touches upon the most basic human fears about disability and physical otherness. Although a certain distancing effect is created by the symbolist convention he uses, together with the fact that the play is set in the Irish heroic age, the play communicates the deep fear of death and of weakness which, according to numerous traditional, ableist narratives, is intrinsic to disability.

Unlike in Yeats's plays, the non-normativity of the bodies substituted by fairies is hardly conspicuous in George Fitzmaurice's "dramatic fantasies." And yet, this is not the only difference between the two writers. As Fintan O'Toole has it, there was "a fundamental difference between his attitude of mind and those of Yeats and Gregory. [...] Fitzmaurice accepted the world, while Yeats and Gregory set about inventing a world" (2007: xxiv). Although Fitzmaurice staged some of his plays at the Abbey Theatre, which promoted the most significant values of the Celtic Twilight, his works very often openly satirize the major concepts and ideas of the revivalists. Yeats and other founders of the Irish Literary Theatre, which gave rise to the Abbey, famously stated that "[w]e will show that Ireland is not 
the home of buffoonery and of easy sentiment, as it has been represented, but the home of ancient idealism" (qtd. in Gregory 1991: 378); Fitzmaurice challenged this idea. He focused on the down-to-earth aspects of life in provincial Ireland and mocked the vices of its people. Therefore, his plays are often compared to those written by John Millington Synge. But, as Clarke notes, "he was no mere imitator" (1967: vii), which is most visible in the way he experimented with the convention of the traditional Irish peasant play in his dramatic fantasies. In this respect, I partly agree with Una Kealy, who argues that

What sets Fitzmaurice's work apart from that of his contemporaries is his use of comedy to create a dramatic experience that pushes the boundaries of realism into a more absurd realm, which is then undercut, by anti-climax or bathos. The one-act plays show Fitzmaurice attempting to resolve metaphysical rather than social problems within his drama. These are not the dreamy whimsical metaphysics of nostalgic nationalism however, but the more knotty problem of how he as a dramatist might portray life as it essentially is, for he is interested in a deeper quality than surface realism. It is not the charting of observable phenomena or presenting a social and material reality that interests him, instead his drama explores and attempts to recreate a world of lived inner experience, along with its joys and difficulties. (2005)

What seems to be missing from Kealy's statement is the fact that the "world of lived inner experience" presented in many of Fitzmaurice's plays is an unsophisticated inner world of simple-minded and superstitious farmers, which often mocks the notion of noble Irish peasants as well as Yeats's idea of "call[ing] to the eye of the mind" (2001a: 297).

This is clearly visible in the way Fitzmaurice alludes to Irish fairy lore in his works. Austin Clarke states that the playwright openly admitted that his "Linnaun Shee" (1924) "was really a satire on Yeats and his cult of the fairies" (1967: x). It is, in fact, an entertaining parody of "Cathleen ni Houlihan," "The Stolen Child," and "The Land of Heart's Desire." There is no changeling to be found in the play, but it clearly alludes to folk stories about fairy abductions and provides a useful context for the discussion of the parodic dimension of Fitzmaurice's dramatic oeuvre. The play explores the concept of the fairy mistress, which was earlier addressed by Yeats in "The Only Jealousy of Emer" (see note 3), showing that according to Irish beliefs, women and children were not the only ones who were susceptible to the misleading charm of fairies. In "Linnaun Shee," the one who is seduced by "a horrid wrinkled old hag" (1967a: 51) who keeps singing "in a horrid, cracked way" (1967a: 52) is a respectable, married, fifty-five-year-old farmer. Once, when he was young, the farmer rejected Linnaun Shee's advances and now, being spellbound, perceives her as a radiant beauty with a charming voice. The story of Jamesie Kennelly's midlife-crisis ends in a comic fashion. Linnaun Shee takes her revenge and eventually replaces Jamesie with a younger man - his brother's future son-in-law - and sends her former victim back home. 
At the end of the play, Jamesie's brother sees "the little high green field at the other side of the quarry," and the new couple entering a tunnel of light (a fairy portal?), but Linnaun Shee is "no longer yellow or withered," and is "setting up to be some sort of a fairy queen" (1967a: 53). This is one of many allusions to Cathleen Ni Houlihan, who uses her song to lure young men to follow her, and at the end of the play undergoes a transformation from a senile old woman into "a young girl [who has] the walk of a queen" (Yeats 2001b: 93). Here, however, her transformation is nothing but a visual illusion, which is yet another way in which Fitzmaurice mocks the false, idealized images of Ireland.

In general, the play suggests that the revivalists were guided by a misconceived, romanticized concept of Irishness, and thus they cherished a false, beautified vision of Ireland. As regards allusions to disability and Irish changeling lore, it is important to note that the abduction is only temporary and that no changeling is introduced in the play. The only form of disability experienced by Fitzmaurice's characters is Jamesie's blindness to the real appearance of the Hag. This serves as a harsh commentary on the idealized representations of Ireland and Irish people by the revivalists and is well-grounded in the ableist, metaphorical perceptions of blindness that place an equality mark between blindness and ignorance, weakness, the lack of insight into the surrounding world, and susceptibility to deception.

One of the reasons Fitzmaurice satirized Yeats and other revivalists was personal. Some years earlier, in 1913, both Yeats and Lady Gregory had discourteously rejected his play "Dandy Dolls." It is conspicuous that "The Magic Glasses" - the dramatic fantasy published by Fitzmaurice before "Dandy Dolls" - premiered at the Abbey Theatre on the $24^{\text {th }}$ of April 1913, with a number of elements already satirizing the revivalists' attempts to ennoble Irish peasantry, which aim it achieved by mocking Irish changeling lore. "The Magic Glasses" tells the story of Jaymony, a satirical alter ago of Fitzmaurice, who at the age of "twenty-four [...] was still at home, never having held a job" (Brennan 2007: 25), hoping to gain recognition as a writer, against his family's expectations. Jaymony is an unfulfilled Irishman who feels jealous of his brothers' success, but seems unable to change his life and therefore seeks refuge in a fantastic land of his heart's desire, which leads to his untimely end.

Referring to the famous phrase "wicked old children," which the playwright used to describe his characters, Arthur E. McGuinness contends that "Fitzmaurice is always sympathetic with his visionaries and dreamers. For him the real wickedness of society is its complacency and self-satisfaction" (1975: 27). It is hard to fully agree with this statement, since no matter how much his solitary characters desire to set themselves apart from their families and community, they are still stuck in traditional ways of thinking and driven by unsophisticated desires. In other words, as McGuinness puts it, they are members of societies which "have never developed an emotional and intellectual maturity to match their biological growth" (1975: 27).

Like Jamesie from "Linnaun Shee," Jaymony considers himself an individualist and despises his family and society. He is hardly comparable to Mary Bruin, 
the romantic dreamer of Yeats's play, and acts like a spoilt child who disrespects everyone around him. Jaymony spends most of his time in the loft where he tries to satiate his unfulfilled desires. He escapes into the world of dreams, which is facilitated by a set of nine magic glasses that he bought from "a brown woman" (1967b: 11), presumably a fairy, who told him: "[f]or it's the pleasure and diversion of the world [...] you will hear and see in them Magic Glasses" (1967b: 12). The set consists of brown, red, and blue glasses that grant Jaymony temporary, illusory fulfilment of his stereotypical male fantasies. The brown glasses satisfy his desire for wealth, prosperity, and a sense of adventure. Looking through them, he enjoys the sight of lavish food, heaps of money, and foreign landscapes that an ordinary Irish peasant would never see. The red glasses give him access to erotic fulfilment, which arouses a narcotic desire for more and more sensations, since, as he puts it, "for ages and ages we'd be in Tirnanogue, and it isn't satisfied we'd be still" (1967b: 12). Finally, looking through the blue glasses, Jaymony sees himself as a warrior leading an army against Saxon invaders. To some extent, the role of the glasses may be compared to that of the magical ointment of legend that, when rubbed into one's eyes, makes one see the parallel world of the fairies. Still, the fact that Jaymony's oneiric visions are incredibly shallow, self-centred male fantasies suggests that the glasses produce subjective illusion, rather than giving real access to Tirnanogue, and it is this idea that satirizes some of the central ideas informing the works of the Irish revivalists, such as their focus on the Celtic heroic period.

The loft in which Jaymony spends most of his time symbolizes his belonging to the airy domain of dreams and desires. It is represented as a place which, in many respects, fits in with Michel Foucault's concept of heterotopia. In particular, it bears a close resemblance to the heterotopia of deviation, in other words, a site "occupied by individuals whose behaviour deviates from the current average standard" (Foucault 1997: 333). As Foucault posits, "[t]he heterotopia enters fully into function when men find themselves in a sort of total breach of their traditional time" (1997: 334). Using his magic glasses, Jaymony experiences a number of alternative, parallel planes of existence, which he perceives as timeless and eternal rather than connected with the linear progress of time. By enabling the interaction between different coexistent realities, the glasses play a similar role to that of the book Yeats's Mary Bruin finds in a thatch. The book was written by a fellow outsider, her father-in-law's grandfather, and had little practical use for the family because it stimulated the imagination and "filled his house with rambling fiddlers, / And rambling ballad-makers and the like" (2001c: 68). This diverted the attention of the readers from their quotidian life and offered them an escape into an alternative, joyful reality. Another heterotopic feature of the loft described in Fitzmaurice's play is conspicuous in the fact that Jaymony's glasses juxtapose "in a single real place different spaces and locations that are incompatible with each other" (Foucault 1997: 334). They transport Jaymony's mind to foreign lands, romantic locations, and the battlefields of the past. In Foucault's terms, the loft also serves as "a space of illusion that reveals how all of real space 
is more illusory" (1997: 335), thus causing the protagonist's confusion as to what is real and what is imagined, which again seems to be a mocking allusion to the Irish revivalists.

The protagonist's unusual behaviour is a source of concern for his parents, who send for the local quack doctor Mr. Quille. Jaymony's propensity for the "queer music" (1967b: 8) that he plays in the loft makes Quille believe that Jaymony is, in fact, a changeling. His initial diagnosis highlights the superstitiousness of the locals and their lack of tolerance for otherness defined not so much in terms of disability, but rather in terms of the adoption of an alternative lifestyle. What makes him even more suspicious is the fact that Jaymony has an excessive appetite, especially for sweets, which has frequently been attributed to fairies. His mother is only successful in luring him down to the kitchen when she adds sugar to his tea and promises to feed him with bread and jam. And when he is about to descend from the loft, Jaymony tells her: "but I'm warning you if the tea isn't drawn the minute I hop down out of this, there isn't a mug in the dresser I won't smash, and I'll break the window, and so every devil around the house will make it the sorry day to you you got in the habit of renayging me in the tea" (1967b: 10). Later, he "eats and drinks rapidly" (1967b: 10), showing his ravenous appetite.

Quille uses a traditional method to reveal Jaymony's real identity. As Yeats explains in his article "Away," referring to Bridget Cleary's case,

A man actually did burn his wife to death, in Tipperary a few years ago, and is no doubt still in prison for it. My uncle, George Pollexfen, had an old servant Mary Battle, and when she spoke of the case to me, she described that man as very superstitious. I asked what she meant by that and she explained that everybody knew that you must only threaten, for whatever injury you did to the changeling the faeries would do to the living person they had carried away. (1920: fn. 39)

In a similar vein, in Fitzmaurice's play, in order to confirm whether Jaymony is a human being, Quille commands: "[p]ut the tongs in the fire and redden it" (1967b: 9). Later, he uses the reddened tongs to threaten Jaymony; he forces him to kneel, performs an exorcism which is a combination of random religious Latin phrases "Sacramento, Dominus vobiscum, mea culpa, mea maxime culpa, kyrie eleison, excelsior!" (1967b: 10), and concludes with a question: "[a]re you Catholic?" (10). Quille makes Jaymony repeat the Trinitarian formula and eventually comes to the conclusion that he is "some sort of a Christian" (1967b: 11).

At the very beginning, the play follows the realistic convention of social satire, and it seems that all of the supposedly supernatural occurrences could easily be explained in a rational way. Even the vision of a devil visiting Jaymony's loft, experienced by his father towards the end of the play, seems to be a hallucination resulting from the excessive consumption of whiskey. Yet the play finishes with a disturbing image - that of Jaymony's death - which brings in a sense of menace 
and undermines the rational explanation of events. After the sudden collapse of the loft, the protagonist is found dead, his throat cut by the magical glasses. ${ }^{4}$ The play leaves both the audience and the characters perplexed as to whether what happened was the result of supernatural intervention.

All in all, Fitzmaurice's play mostly focuses on mocking and challenging the revivalist image of noble peasants and does not explore the deep traumas rooted in Irish society, which found an expression in local fairy lore. The nature of otherness in Fitzmaurice's plays is as trivial as the lives of his characters. The fear it provokes is the fear of losing one's social status in the village, while the desires it kindles are a trivial longing for wealth, sex, and adventure, experienced by Irish peasants whose lives revolve around digging their fields and discussing farming with their neighbours.

To conclude, as Barbara O'Connor argues, “[t]he establishment of a politically independent state in Ireland in 1922 was preceded and followed by an intensive cultural project of nation building that was marked by a public interest in embodied identities and a concerted public effort to mould individual bodies to the shape of the 'ideal' body politic of the new state" (2005: 89). By alluding to the Irish stories of fairy abductions and substitutions, Yeats and Fitzmaurice create some space for bodily variety and nonconformist behaviour in Irish drama. Although their changelings - their unruly conduct or ugly and dysfunctional bodies - are sometimes relegated to the textual margin, the two playwrights successfully tackle two different (and in a sense, complementary) aspects of these fantastic creatures' otherness. Yeats's exploration of Irish changeling lore touches upon the problem of otherness defined through physical impairment. The changelings depicted in his plays are seen as repulsive objects of abjection that produce a truly uncanny experience. In Fitzmaurice's "The Magic Glasses," by contrast, the figure of the changeling is sublimated, deprived of its abject, bodily dimension and approached solely from the social perspective. The text is a pastiche of a peasant play, which ridicules the dramatic conventions of the Abbey and the everyday lives of Irish peasants, where there was little room for non-conformism or imagination. And yet, what remains noticeable in the works of both playwrights is the fact that the physical otherness of the changelings is either marginalized or conspicuous by its absence, which suggests the reluctance of the Irish playwrights of the Irish Revival - even those as experimental as Yeats or as critical as Fitzmaurice - to fully embrace the local changeling lore together with its uncanny aspects resulting from physical "imperfection."

\section{Notes}

The example was taken from Lady Gregory's Visions and Beliefs in the West of Ireland. The Irish spelling of "Shee" (fairy people).

In this play Yeats makes an allusion not only to Irish changeling lore, but also to the supernatural figure of Leanhaun Shee, which he describes in Fairy and Folk Tales of Ireland in the following way: 
The Leanhaun Shee (fairy mistress), seeks the love of mortals. If they refuse, she must be their slave; if they consent, they are hers, and can only escape by finding another to take their place. The fairy lives on their life, and they waste away. Death is no escape from her. She is the Gaelic muse, for she gives inspiration to those she persecutes. The Gaelic poets die young, for she is restless, and will not let them remain long on earth - this malignant phantom. (1998: 76) The scene menacingly anticipates the death of the revivalists who fought in the Easter Rising.

\section{References}

Brennan, Fiona (2007) George Fitzmaurice: 'Wild in His Own Way.' Dublin: Carysfort.

Clarke, Austin (1967) 'Introduction.' In: Austin Clarke (ed.) The Plays of George Fitzmaurice: Dramatic Fantasies. Dublin: Dolmen, vii-xvi.

Eberly, Susan Schoon (1988) 'Fairies and the Folklore of Disability: Changelings, Hybrids and the Solitary Fairy.' Folklore 99 (1): 58-77.

Fitzmaurice, George (1967a) 'The Linnaun Shee.' In: Austin Clarke (ed.) The Plays of George Fitzmaurice: Dramatic Fantasies. Dublin: Dolmen, 39-56.

Fitzmaurice, George (1967b) 'The Magic Glasses.' In: Austin Clarke (ed.) The Plays of George Fitzmaurice: Dramatic Fantasies. Dublin: Dolmen, 1-18.

Foucault, Michel (1997) 'Of Other Spaces: Utopias and Heterotopias.' In: Neil Leach (ed.) Rethinking Architecture: A Reader in Cultural Theory. London: Routledge, 330-36.

Gregory, Augusta (1991) 'Our Irish Theatre.' In: John P. Harrington (ed.) Modern Irish Drama. New York: Norton, 377-86.

Kealy, Una. (2005) 'Mysterious and Fantastic Strange': The Life and Art of George Fitzmaurice (fragments).' Diss. U. of Ulster. Ricorso. http://www.ricorso.net/rx/az-data/authors/f/Fitzmaurice_G1/life.htm. Accessed on June 11, 2017.

Kiberd, Declan (1996) Inventing Ireland: The Literature of the Modern Nation. London: Vintage.

Kristeva, Julia (2012) Letter to Jean Vanier (10 August 2009). In: Katarzyna and Piotr Wierzchosławscy (eds. and trans.) (Bez)sens słabości: Dialog wiary z niewiara o wykluczeniu. Poznań: W drodze, 35-52.

Lysaght, Patricia (1997) 'Fairylore from the Midlands of Ireland.' In: Peter Narváez (ed.) The Good People: New Fairylore Essays. Lexington: The UP of Kentucky, 22-46.

McDevitt, Patrick F. (2004) May the Best Man Win: Sport, Masculinity, and Nationalism in Great Britain and the Empire, 1880-1935. Houndmills: Palgrave MacMillan.

McGuinness, Arthur E. (1975) George Fitzmaurice. London: Associated UP.

MacPherson, D. A. J. (2012) Women and the Irish Nation: Gender, Culture and Irish Identity 1890 1914. New York: Palgrave MacMillan.

Mac Philib, Séamas (1991) 'The Changeling: Irish Versions of a Migratory Legend in Their International.' Béaloideas 59: 121-31. JSTOR. https://www.jstor.org/stable/20522381. Accessed on May 30, 2017.

Miles, M. (2001) 'Martin Luther and Childhood Disability in $16^{\text {th }}$ Century Germany.' Journal of Religion, Disability \& Health 5(4): 5-36. Taylor and Francis Online. http://www.tandfonline. com/doi/abs/10.1300/J095v05n04_02. Accessed on March 28, 2017.

Monteith, Ken (2010) 'Enabling Emer, Disabling the Sidhe: W. B. Yeats's The Only Jealousy of Emer.' South Carolina Review 43(1): 99-115.

Mooney, James (1887) 'The Medical Mythology of Ireland.' Proceedings of the American Philosophical Society 24(125): 136-66. JSTOR. https://www.jstor.org/stable/983129. Web. Accessed on March 27, 2017.

O'Connor, Barbara (2005) 'Sexing the Nation: Discourses of the Dancing Body in Ireland in the 1930s.' Journal of Gender Studies 14(2): 89-105. 
O’Toole, Fintan (2007) 'Foreword.' In: Fiona Brennan (ed.) George Fitzmaurice: 'Wild in His Own Way.' Dublin: Carysfort, xiii-xviii.

Purkiss, Dianne (2007) Fairies and Fairy Stories: A History. Stroud: Tempus.

Smith, Peter Alderson (1987) W. B. Yeats and the Tribes of Danu: Three Views of Ireland's Fairies. Gerrards Cross: Colin Smythe.

Valera, Eamon de (1991) 'The Undeserted Village Ireland.' In: Seamus Deane (ed.) The Field Day Anthology of Irish Writing. Vol. 3. Derry: Field Day, 747-50.

Wilby, Emma (2010) The Visions of Isobel Gowdie: Magic, Witchcraft, and Dark Shamanism in Seventeenth-Century Scotland. Brighton: Sussex Academic P.

Yeats, William Butler (1920) 'Away.' In: Augusta Gregory and William Butler Yeats (ed.) Visions and Beliefs in the West of Ireland Collected and Arranged by Lady Gregory: with Two Essays and Notes by W. B. Yeats. New York: Knickerbocker. Project Gutenberg, https://archive.org/details/ visionsbeliefsin00gregrich. Accessed on Sept. 22, 2014.

Yeats, William Butler (ed.) (1998) Fairy and Folk Tales of Ireland. New York: Touchstone.

Yeats, William Butler (2000) 'Under Ben Bulben.' The Collected Poems of W. B. Yeats. Ware: Wordsworth, 301-4.

Yeats, William Butler (2001a) 'At the Hawk's Well.' In: Clark, David R., and Rosalind E. Clark (eds.) The Collected Works of W. B. Yeats. Vol. 2. New York: Scribner, 297-306.

Yeats, William Butler (2001b) 'Cathleen Ni Houlihan.' In: Clark, David R., and Rosalind E. Clark (eds.) The Collected Works of W. B. Yeats. Vol. 2. New York: Scribner, 83-94.

Yeats, William Butler (2001c) 'The Land of Heart's Desire.' In: Clark, David R., and Rosalind E. Clark (eds.) The Collected Works of W. B. Yeats. Vol. 2. New York: Scribner, 65-82.

Yeats, William Butler (2001d) 'The Only Jealousy of Emer.' In: Clark, David R., and Rosalind E. Clark (eds.) The Collected Works of W. B. Yeats. Vol. 2. New York: Scribner, 317-28.

Katarzyna OjRzyŃska is an Assistant Professor at the Department of Studies in Drama and Pre1800 English Literature, University of Lodz, Poland. Her research interests focus on Irish studies and cultural disability studies. She is the author of "Dancing as if language no longer existed": Dance in Contemporary Irish Drama (Reimagining Ireland 61, Peter Lang, 2015). She is also a founding member of ULCIS (University of Lodz Centre for Irish Studies).

Address: dr Katarzyna Ojrzyńska, Department of Studies in Drama and Pre-1800 English Literature, Institute of English Studies, University of Lodz, ul. Pomorska 171/173, 90-236 Łódź, Poland. [katarzyna.ojrzynska@uni.lodz.pl] 